\title{
Reflektioner kring Renée Frangeurs avhandling "Yrkeskvinna eller makens tjänarinna? Striden om yrkesrätten för gifta kvinnor i mellankrigstidens Sverige"
}

\author{
Av Marie Eriksson, studerande vid Växjö universitet
}

\section{Arbete kvinnans väg till frihet?}

Att tala om gifta kvinnors yrkesrätt implicerar enligt min mening en i grunden positiv syn på begreppet arbete. Det har inte varit ovanligt, vilket jag kommer att visa i denna artikel, att man istället talat om att just gifta kvinnor, av ett eller annat skäl, varit tvungna att arbeta för att försörja sig. För att de har en arbetslös man, en lågavlönad man, en frånvarande man osv. Den gifta kvinnans arbete har alltså satts i relation till mannens arbete. Idag hör argumenten för (gifta) kvinnors arbete ofta ihop med att det är omöjligt att kunna leva enbart på mannens lön i ett konsumtionssamhälle, med höga krav på standard och höga utgifter. Även den gifta kvinnan måste således arbeta. Med en dylik syn försvinner enligt min mening arbetets emanciperande och utvecklande potential. Därmed inte sagt att jag vill romantisera allt arbete då jag är medveten om att det finns många arbeten som snarare är förslavande än befriande. Vad jag däremot vill peka på är skillnaden i synen på mäns och kvinnors arbete. Talet om att män är tvungna att arbeta är inget man hör särskilt ofta. Inte heller om mäns rätt till arbete. Däremot deras plikt att försörja. Dessa bilder eller tankefigurer kring män, kvinnor och deras relation till arbete är historiska artefakter som i viss mån fortfarande präglar våra värderingar och vårt handlande och som vi på olika sätt bidrar till att reproducera.

För oss, idag, i Sverige, ses det dock som en självklarhet att kvinnor ska ha samma rätt till arbete och utbildning - som män - med följd att vi inte ens tror att vi behöver argumentera för det. Denna rätt gäller alla kvinnor oavsett civilstånd. Trots detta är det ändå fortfarande gifta kvinnors (med barn) arbete, och inte deras mäns, som ifrågasätts i tider av lågkonjunktur. I enlighet med den rådande jämställdhetsdiskursen framförs dock denna syn oftast implicit genom mediernas rapportering om stress och ohälsa bland dubbelarbetande mödrar, barns långa vistelser på dagis och politikers förslag om vårdnadsbidrag. Det är vidare mer vanligt att kvinnor har lägre löner, att de betraktas och behandlas som en reservkader av arbetskraft vilket avspeglas i att det främst är kvinnor som arbetar deltid ofta mot sin egen vilja - då det inte finns heltidstjänster att tillgå inom vård och omsorgssektorn där kvinnorna dominerar. Det är också vanligare att kvinnor innehar vikariat än män.[1]

För att återknyta till den inledande synen på arbete som en positiv rättighet menade redan Simone de Beauvoir att det var genom kvinnans deltagande i arbete som hon skulle bli fri. Kvinnors abstrakta rättigheter i form av lagstiftning blir, enligt de Beauvoir, först till konkreta möjligheter genom arbetet. Genom att delta i produktionen kan kvinnan utveckla sin mänskliga förmåga samtidigt som ett ekonomiskt oberoende av mannen möjliggörs genom detta arbete.[2] Det är genom detta ekonomiska oberoende av mannen som den emancipatoriska potentialen i arbetet finns för den gifta kvinnan. Om man då lagstiftar mot gifta kvinnors yrkesrätt finns det, i enlighet med de Beauvoirs resonemang, ingen möjlighet för den gifta kvinnan att bli fri.

Utifrån de Beauvoirs resonemang kom den svenska gifta kvinnan att bli fri i den meningen 
att hon tillerkändes en legal rätt till yrkesarbete. Sett ur ett historiskt perspektiv har allt fler kvinnor i Sverige, även gifta, gått ut i förvärvslivet, vilket har bidragit till en ökad jämlikhet i fråga om ekonomiskt oberoende. Samtidigt har ojämlikheten mellan könen bevarats på arbetsmarknaden i form av löneskillnader. All ojämlikhet till trots ses det idag av de flesta som en självklarhet att även kvinnor ska ha lika formell och legal rätt att arbeta. Men vägen dit var allt annat än självklar, vilket Frangeur visar i sin avhandling.

Med utgångspunkt i Frangeurs avhandling har jag för avsikt att i denna artikel diskutera om huruvida konstruktionen av förvärvsarbetets genus kom att transformeras i Sverige under mellankrigstiden, vilket är intimt sammanflätat med konstruktionen av manlighet och kvinnlighet.

\section{Framsteg och bakslag}

I 1920- och 30-talets Sverige höjdes företrädesvis manliga röster för att begränsa gifta kvinnors rätt till arbete. Denna debatt startade 1925 då en ung socialdemokratisk riksdagsman, Lindberg, lade fram en motion om att begränsa gifta kvinnors rätt till statstjänst. Mot bakgrund av de nyvunna rättigheter som kvinnor hade fått tiden före denna motion kan den, enligt min mening, ses som ett uttryck för vad Susan Faludi benämner "backlash", dvs ett bakslag för kvinnorna.[3] Gifta kvinnor i Sverige hade inte bara tillkämpat sig politiska och medborgerliga rättigheter genom den allmänna rösträttens införande 1921, de hade dessutom blivit myndiga vilket innebar att de hade rätt att själva bestämma om de skulle arbeta. Dessutom fick de råda över sin egen inkomst. Den gifte mannens husbondemakt hade sålunda urholkats och männen hade fått ökad konkurrens på offentliga arenor. Den nya giftermålsbalken stadgade dessutom att såväl mannen som kvinnan hade samma skyldighet att bidra till familjens försörjning. [4] Detta var något nytt. Tidigare, i 1734-års lag, fanns inte ens uttryckt att det var mannen som skulle försörja sin hustru, det var en norm som var så förgivettagen att den, enligt Monika Edgren, "ansågs ligga i äktenskapets väsen".[5] Alltså är det inte att förvånas över att utmaningen mot denna traditionella försörjarmanlighet, som dessutom under 1800-talet förstärkts med hjälp av borgerlighetens manlighetsideal, möttes med motstånd. Genom behörighetslagen som antogs 1923 och trädde i kraft 1925 fick kvinnor, såväl ogifta som gifta dessutom i princip samma rättigheter som män att inneha statliga tjänster som läkare, statsråd, universitetslärare $\mathrm{m}$ m.[6]

Införandet av dessa reformer kom inte att avsluta kampen för kvinnors emancipation, utan bidrog istället att förstärka den samtidigt som de utlöste en kamp kring konstruktionen av manligt och kvinnligt. En kamp som kom till uttryck i debatten kring gifta kvinnors rätt till yrkesarbete. Manligheten hade tidigare varit knuten till den maktbas som husbondeväldet utgjorde, dvs till mannen som försörjare av och förmyndare över kvinnan. Båda dessa baser för mannens makt hade förändrats på kort tid genom att kvinnan hade blivit myndig och givits utökade rättigheter genom behörighetslagen att försörja sig själv. Den rådande genusordningen var i gungning; isärhållandet mellan könen hotades genom att kvinnor fick formell rätt att inträda på männens arenor och hierarkin hotades genom att mannen inte längre var formellt och legalt överordnad sin hustru. Försörjarmanligheten och den makt som var knuten till denna var således hotad, och Lindbergs motion om att begränsa yrkesrätten för kvinnor kan ses som ett uttryck för detta hot. Genom denna motion, som kom att följas av flera, kom en debatt att föras under mellankrigstiden som på ett ytligt plan handlade om gifta kvinnors yrkesrätt men på ett djupare plan om maktrelationen mellan könen och om konstruktionen av manlighet och kvinnlighet.

\section{Mellankrigstidens husmoderskontrakt}

Frangeur har i sina teoretiska utgångspunkter inspirerats av Yvonne Hirdmans teori om genussystemet. Enligt denna teori präglades mellankrigstiden av en genusordning som på en 
generell makronivå kan liknas vid ett "husmoderskontrakt". Denna genusordning innebar att kvinnan på de flesta plan i samhället var underordnad mannen och att det var han som utgjorde normen. Genusarbetsdelningen förutsatte husmoderskontraktet "en manlig yrkesarbetande försörjare och en kvinnlig försörjd hemarbetande moder".[7] Jag instämmer i Frangeurs kritik mot denna teori då den är alltför strukturalistisk och inte tar hänsyn till att husmoderskontraktet kunde rubbas, även på en strukturell nivå genom mänskligt handlande. Trots att vi som människor styrs av omgivande strukturer som t ex klass och kön, vilka påverkar vad som är möjligt att tänka och handla, så går det inte att bortse från att det är människor som skapar historia genom sitt handlande. Ett handlande som vi, inte minst genom att studera historien, har sett kan förändra även de mest sega strukturer. Det som enligt Hirdman kan påverka och förändra genussystemet är yttre strukturella faktorer som t ex krig och ekonomiska kriser. Människors möjligheter att som handlande aktörer förändra genusordningen bortser hon ifrån, vilket enligt min mening leder till en statisk syn på människan som skapare av sin egen historia. Trots sin aktörsinriktade studie bortser Frangeur dock inte från strukturella förhållanden utan kopplar sin analys till den omgivande kontexten. Bland annat visar hon hur de ekonomiska konjunkturerna med efterföljande arbetslöshet påverkade genusrelationen. Det var nämligen i tider av lågkonjunktur som röster mot kvinnans förvärvsarbete höjdes. I början av 1920-talet rådde en hög arbetslöshet i Sverige, ca $20 \%$ av befolkningen stod utanför arbetsmarknaden. I den ekonomiska krisens spår hade 10000 lägre manliga tjänster försvunnit inom de statliga verken samtidigt som 2500 nya tjänster hade skapats för kvinnor.[8] Eftersom kvinnor var billigare att anställa var det från statligt håll rationellt att i kristider föredra kvinnliga anställda framför manliga.

Franguers bild av mellankrigstidens genusordning på en makronivå blir på olika sätt en annan än den som Yvonne Hirdman lanserat genom sitt Husmoderskontrakt som kännetecknas av renodlade idealtyper som hemmafrufamiljen och den manliga enförsörjarmodellen.[9] Hirdmans Husmoderskontrakt bygger på statististiska beräkningar som visar att kvinnors förvärvsarbete minskade dramatiskt på 1930-talet. I polemik med denna forskning visar Frangeur på ett övertygande sätt att de gifta kvinnorna ökade i antal under hela mellankrigstiden särskilt inom tjänstesektorn. Hon synliggör hur svensk officiell statistik kraftigt underskattat kvinnors arbetsinsatser vid denna tiden genom att inte inkludera jordbrukarhustrurs arbete och gifta kvinnors deltidsarbete i statistiken.[10] Det är intressant hur beräkning av statistik kan påverka vår bild av det förflutna men också, vilket Frangeur lyfter fram, hur statistik kan påverka synen på kvinnors arbete och hur denna på sikt kan bli normerande. Detsamma gäller idag då man beräknar arbete. Det arbete som syns i statistiken är vanligen det avlönade förvärvsarbetet människor utför, medan det oavlönade arbetet i hushållet, som till största delen utförs av kvinnor, vanligen osynliggörs. Om vi idag skulle räkna in det obetalda hushållsarbetet och omsorgen om barn skulle vi förmodligen kunna konstatera att ett slags husmoderskontrakt fortfarande existerar. Hursomhelst går det rent statistiskt att konstatera att nära två tredjedelar av det obetalda arbetet i Sverige utförs av kvinnor.[11]

\section{Klass och kön}

I initiativet till Lindbergs motion 1925 om att utreda en begränsning av gifta kvinnors rätt till statstjänst kan det förefalla anmärkningsvärt, menar jag, att förslaget kom från en socialdemokrat eftersom vi fått lära att det var ett parti som förespråkade jämlikhet, demokrati och rättvisa. Det tidigare motståndet mot att införa politisk rösträtt för kvinnor hade dessutom haft sitt främsta fäste inom högern och hos de konservativa medan vänstern och liberalerna förespråkade allmän och lika rösträtt. Frangeur menar dock att denna politiska splittring inte fanns kring frågan om gifta kvinnors rätt att yrkesarbeta. De statliga tjänster som förbudet främst riktade sig mot hade blivit en språngbräda för män inom arbetarklassen - åtminstone för de män som i likhet med förespråkarna tillhörde en arbetararistokrati och som hyllade det borgerliga familjeidealet, den manliga enförsörjarmodellen.[12] Därför kom debatten i riksdagen under 1920-talet att inte bara innehålla genusargument, utan även klassargument. Man kritiserade behörighetslagen för 
att skapa en ny överklass bland familjer med två statliga tjänster, medan familjer med bara en tjänst kom att benämnas proletariat.[13] Klassargumenten apellerade säkert till den politiska vänstern, och därmed föreföll det inte som om det enbart handlade om en könsfråga. Lindberg fick dessutom stöd från ledamöter från religiöst färgade och agrart präglade län där motståndet mot modernisering och ett försvar av gamla traditioner av typen "hustrun ska stå vid spisen" (eller mjölka korna) var som störst.[14] Trots inslag av klassargument i debatten menar Frangeur att det argument som var mest förekommande under riksdagsdebatten under de tre första åren var försvaret av mannens rätt till arbete, eftersom han betraktades som försörjare och kvinnans naturliga plikter var i hemmet.[15] Klassbegreppet var således centralt i debatten, men det blir tydligt att många av männen hade klassöverskridande intressen av att bevara genusordningen och sin egen position som familjeförsörjare. Det borgerliga familjeidealet som växte fram på 1800-talet med doktrinen om de två sfärerna, där den manliga sfären var offentlighet och arbete och den kvinnliga det privata och hemmet, var den genusordning Lindgren och hans anhängare förespråkade. Denna genusordning försökte man stabilisera genom att essentialisera manlighet och kvinnlighet. Genusolikheterna sågs därmed som naturgivna, vilket en debattör uttryckte med orden: "Naturen skapade olikhet mellan könen och inte likställighet".[16]

Behörighetslagen hann alltså inte mer än träda i kraft och ge kvinnor lagstadgad rätt till statliga tjänster förrän det gjordes försök att med såväl klass- som genusargument mota bort dem från desamma. Förespråkarna för en utredning menade att det var ett stort problem med gifta kvinnor i statlig tjänst eftersom de tvingade bort bättre behövande familjeförsörjare från sina arbeten. Genom att utestänga gifta kvinnor från arbete skulle man lösgöra fler arbetstillfällen för andra, mer behövande grupper, dvs män och ogifta kvinnor. Kvinnorna i statlig tjänst hade blivit hotande många och uppfattades således som konkurrenter till den manlige familjeförsörjaren. Om vi riktar ljuset mot vår egen tid kan detta, enligt min mening, jämföras med att man idag allt oftare hör talas om det hot feminiseringen av skolan utgör. Att majoriteten av lärare idag främst är kvinnor bidrar enligt vissa debattörer till att skapa alltifrån lägre löner, lägre yrkesstatus till ett ökat antal värstingar bland de manliga eleverna. Däremot talar man aldrig om en maskulinisering då man omskolar f d personal med ledaregenskaper ur försvaret för att ta anställning inom skolan. Överhuvudtaget talas det inte om en maskulinisering i mansdominerade branscher som teknik och ekonomi. Hur vanligt är det att maskuliniseringen av börsen ses som ett problem jämfört med feminiseringen av skolan? Förmodligen hänger det samman med att män, pengar och makt är så intimt förknippade att vi inte ens ifrågasätter det. Skolan däremot, åtminstone de högre stadierna, har inte alltid varit en given arbetsplats för kvinnor, och då de i början på 1900-talet försökte få tillgång till dessa tjänster, med samma lön som männen, restes redan då röster om "gosskaraktärens feminisering" och "feminismen och läroverkens förfall".[17] Ibland verkar det onekligen som om de gamla grekernas historiesyn "inget nytt under solen" har giltighet än idag.

\section{Konstruktion av manlighet och kvinnlighet}

Trots förespråkarnas högljudda argumentation med krav på utredning om gifta kvinnors rätt till yrkesarbete fanns det motståndare till inskränkningar i denna rätt. I riksdagsdebatten framträder det därmed tydligt att konstruktionen av genus handlar om en konfliktfylld process, en process som framträder i människors sociala relationer och i deras språkliga utbyte med varandra. Denna process är stadd i ständig rörelse varför den, vilket vi också ska se, kan leda till förändring. De som var motståndare till en utredning betonade rättviseoch rättighetsargument, dvs att kvinnor genom behörighetslagen tillskrevs samma rätt som männen och att de skulle vara likställda. De lyfte också fram nödvändigheten av att vissa kvinnor, särskilt ur lägre klasser, av praktiska skäl var tvungna att arbeta och att det inte var mer självklart att en man skulle arbeta än att hans hustru skulle göra det.[18] Man pekade vidare på den nya giftermålsbalken vilken stadgade mannens och hustruns lika försörjningsplikt, och en lag mot gifta kvinnor i statlig tjänst, menade man, skulle inte råda bot på det ökande arbetslöshetsproblemet. I likställighetens anda betonade motståndarna till 
en utredning att behovsprincipen inte skulle vara styrande för vem som skulle få statlig tjänst, utan principen om "förtjänst och skicklighet".

Frangeur gör alltså en analys av de olika aktörernas argument och strategier och debatten ser hon som uttryck för olika klass- och manlighetsstrategier. Hon använder sig av den relativt nya s.k. mansforskningen för att visa hur olika grupper av män företräder olika manlighetsstrategier. Det är, menar jag, en nödvändighet att studera såväl män som kvinnor som historiska subjekt. Eftersom manlighet lika lite som kvinnlighet är något essentiellt bör det problematiseras, vilket den tidigare genusforskningen ofta har bortsett från i sin emfas på kvinnan som studieobjekt.[19] Vidare är det centralt att studera genus relationellt eftersom det som är manligt konstrueras i relation till det som är kvinnligt och vice versa. Enligt sociologen R.W. Connells teori finns det i västerländska samhällen en hegemonisk manlighet, vilket kan definieras som "den konfiguration av genuspraktik som innehåller det för tillfället accepterade svaret på frågan om patriarkatets legitimitet".[20] Eftersom patriarkatets legitimitet på olika sätt kan undergrävas är den hegemoniska manligheten föränderlig. Nya grupper, av såväl kvinnor och män, kan utmana den gamla hegemonin och skapa en ny varför hegemoni är en historiskt föränderlig relation. Den hegemoniska manligheten är dock inte den enda enligt Connell eftersom det inom denna hegemoni existerar genusrelationer som bygger på dominans och underordning mellan olika grupper av män. Det finns alltså över- och underordnade maskuliniteter inom genusordningen. Trots att majoriteten av män inte tillhör den hegemoniska manligheten så kan de ändå dra fördelar av den eftersom "de tillgodogör sig den patriarkaliska utdelningen, dvs de fördelar som män vinner av kvinnornas underordnade ställning".[21] Utifrån Connells beskrivning av de inre relationerna i genusordningen som hegemoni, underordning, delaktighet och marginalisering finner Frangeur i sin analys av riksdagsdebatten vad hon kallar tre olika manlighetsstrategier: "familjeförsörjarstrategin", "medelvägsmanligheten" och "likställighetsstrategin". Med begreppet manlighetsstrategi avser hon "det politiska uttrycket för att uttrycka, stödja eller försvara en viss manlighet".[22]

\section{Manlighetsstrategier}

"Familjeförsörjarmanligheten", så som den framträder i debatten om gift kvinnas yrkesrätt, är den som Lindberg företräder och som kännetecknas av ett motstånd mot att "försörjarmanligheten" utmanats av behörighetslagen och kvinnorörelsen. Det var dock inte denna manlighetsstrategi som avgick med segern i riksdagsdebatten på 1920-talet, utan "medelvägsmanligheten". Som företrädare för denna strategi ställs P A Hansson i det att han motsatte sig en lagstiftning mot gift kvinnas yrkesrätt av demokratiska jämlikhetsskäl, kallade motståndet mot gifta kvinnors yrkesrätt för "manlig skråpolitik" samtidigt som han pläderade för att kvinnans naturliga plats, i goda tider, var i hemmet.[23] Det är statsministerns position som en åsna mellan två hötappar eller med ett ben i en traditionell genusordning, och ett annat i en modern som gör att man kan definiera honom som en medlöpare till den hegemoniska manligheten enligt Connells termer. Hos "medelvägsmanligheten" saknas dock de aggressiva reaktionära utfallen mot yrkesarbetande hustrur som återfinns i familjeförsörjarmanlighetens argumentation. Istället ser man kvinnors arbete mer som ett nödvändigt ont, ett ont som i det framtida socialistiska samhället ska utplånas. Den tredje manlighetsstrategin är "likställighetsmanligheten". I 1920-talets debatter utgjorde den en mycket liten grupp av ledande politiker inom socialdemokratin och liberalerna, t ex Wigforss och Västberg, som menade att män och kvinnor skulle vara jämlika och ha samma rättigheter.

Jag finner det intressant att dessa politiker framstår som mindre konservativa än de yngre socialdemokratiska "familjeförsörjarmanligheterna" i riksdagen. Möjligen kan detta bero på att de har en högre, mer befäst maktposition, dvs är hårdare knutna till samhällets politiska makt och därmed inte upplevde kvinnoemancipationen som ett lika stort hot. Oviktigt är inte heller, vilket Frangeur lyfter fram, att de var gifta med kvinnor som var politiskt aktiva yrkeskvinnor.[24] Det privata och det politiska tycks hänga samman även för män. Istället för att idealisera doktrinen om de två sfärerna förespråkade de likställighet såväl i hemmet 
som på arbetsmarknaden.[25] Det blir alltså tydligt i Frangeurs analys att det existerar flera olika manligheter i ett samhälle samtidigt, och att de på olika sätt förhåller sig till den hegemoniska manligheten - antingen som ett stöd för den eller som ett utmanande alternativ till den. Detsamma gäller som vi ska se kvinnligheterna.

\section{Kvinnlighetsstrategier}

Kvinnorna i riksdagen var vid denna tiden få, och flera av dem motsatte sig förändringar i behörighetslagen dock inte alla. Kvinnors idéer och politiska strategier på 1920-talet kom istället främst till uttryck i kvinnoorganisationerna varför Frangeur även har studerat kvinnorörelsens argumentation i debatten kring gifta kvinnors rätt till yrkesarbete. De kvinnorörelser hon avgränsat sig till är Socialdemokratiska kvinnoförbundet (SSKF), Fredrika Bremerförbundet (FBF), Sveriges Husmodersföreningars riksförbund (SHR), Frisinnade kvinnors riksförbund (FKR) och Yrkeskvinnors riksförbund (YKR). Redan 1925, då Lindbergs motion lades fram, tog diskussionen kring gifta kvinnas yrkesrätt fart även inom delar av denna kvinnorörelse. Frangeur visar dock att kvinnorörelsen på 1920talet, trots att de samarbetade i andra sakfrågor, långt ifrån var enad kring frågan om gifta kvinnors yrkesrätt. Precis som i riksdagsdebatten fanns det såväl motståndare som förespråkare. Det fanns, menar hon, ingen "kollektiv identitet" inom kvinnorörelsen på 1920-talet vilket inte är att förvåna då kvinnorörelsen var långt ifrån homogen, utan snarare bestod av kvinnor ur olika klasser, i olika positioner och med olika preferenser.

Simone De Beauvoir pekar i Det andra könet på problematiken kring att se kvinnor som en kollektiv, homogen enhet. Klass kan enligt hennes resonemang utgöra en mer grundläggande kategori än genus i den meningen att kvinnor i första hand solidariserar sig med sin klass och inte sitt kön.[26] Detta blir tydligt i debatten om gift kvinnas yrkesrätt då i synnerhet socialdemokratiska kvinnoförbundet under 1920-talet var splittrat i frågan.

Deras klassolidaritet med männen inom SAP fick ofta gå före deras gemensamma intressen med andra kvinnor. Klassolidariteten var således starkare än kvinnosolidariteten, vilket överensstämmer med de Beauvoirs resonemang om att kvinnor är hårdare bundna till män ur samma klass än till andra kvinnor ur andra klasser, en bindning som uppstått inte minst p g a deras ekonomiska beroende av män, men också p g a att kvinnor vinner på att liera sig med det kön som har makt.[27] Kvinnorörelsen var vidare, under 1920-talet starkt influerad av de rådande husmodersidealen och präglades av ett särartstänkande. Både i SSKF och inom SHR dominerade en biologiserande bild av kvinnan som moder med en given naturlig plats i hemmet. Denna kvinnlighetskonstruktion kan, enligt Frangeur, ses som en pendang till den försörjar- och medelvägsmanlighet som dominerade riksdagsdebatten 1925 - 34.[28] I FBF och bland de frisinnade kvinnorna fanns dock ett mer uttalat yrkeskvinnoideal då de rekryterade medlemmar främst ur medelklassen och bland förvärvsarbetande kvinnor.

\section{Kvinnors arbete ett dubbeltjänstsystem?}

På 1930-talet kom en ny attack mot kvinnans rätt till arbete i riksdagen, vilket inte är märkligt mot bakgrund av att arbetslösheten i Sverige hade ökat till över 20 \% igen. Debatten i riksdagen hade en spill-over-effekt även på andra arenor som LO-kongresser, fackliga kongresser och SAP-kongresser där frågan kom att behandlas under 1930talet.[29]

Riksdagsdebatten kom dock att skilja sig från hur den sett ut på 1920-talet i vissa avseenden. Dels fanns det på 1930-talet fler förespråkare för förbud eller inskränkningar i gifta kvinnors rättigheter än tidigare, dels var det nu Bondeförbundet som tydligast drev frågan, varför det kom att bli en tydligare uppdelning mellan vänstern och högern i frågan än på 1920-talet. Argumenten var i stort sett de samma men nytt var begreppet dubbeltjänstsystem som infördes i en motion av en bondeförbundare. Begreppet härrörde från det tyska "doppelverdiener" och syftade på att det fanns fler än en (statlig) tjänst i en familj, vilket definierades som onormalt och användes som skällsord mot gifta kvinnors 
arbete i största allmänhet.[30] Detta dubbeltjänstsystem ville motionärerna avveckla genom att gifta kvinnor, precis som i Tyskland, skulle tvingas att avgå från sina statliga tjänster då de gifte sig. Det intressanta med begreppet dubbeltjänstsystem är, enligt min mening, att det användes så flitigt att det $\mathrm{t}$ om integrerades i utredningsspråk. På så sätt kan begreppet i sig få "makt över tanken" hos utredare och riksdagsmän, dvs att det var något onaturligt med gifta kvinnors förvärvsarbete.[31] Särskilt onaturligt var det i bondeförbundarna Nybloms och Walléns ögon, dvs bland dem som införde begreppet och som krävde att staten främst skulle garantera svenska män arbete.[32] De gjorde således inte enbart distinktioner gentemot kvinnor i konstruktionen av manlighet utan även gentemot utländsk manlig arbetskraft, helt i linje med sina fascistiska och antifeministiska ideal. Detta visar hur genus interagerar även med etnicitet och klass. Även Connell visar hur vita mäns maskulinitet inte enbart konstrueras i relation till vita kvinnor, utan också till svarta män.[33] Genus är således inte allt men mycket.

På de fackliga kongresserna framkom det att en stor andel kvinnor inom såväl offentlig som privat tjänst, även där det inte existerade något legaliserat tvång, avsade sig sina tjänster då de gifte sig eller blev gravida. Det behövdes således inte alltid en lag för att fördriva kvinnorna tillbaka till hemmets sfär. Det yttre trycket i form av normer och förväntningar kunde också utgöra en starkt tvingande kraft i denna riktningen. Eftersom föräldraskapet var så intimt förknippat med moderskapet i den samtida diskursen var det säkert viktigare för många kvinnor att vara en god mor, vilket betydde att man skulle vara hemma med sina barn, än att få utvecklas eller bli ekonomiskt oberoende genom förvärvsarbete. Att dessa normer är seglivade är tydligt även mot bakgrund av att kvinnor i Sverige idag använder 88 \% av de dagar då föräldrapenning utgår.[34] Trots att mycket har hänt lever fortfarande gamla föreställningar kvar om vad som konstituerar en god mor och en god far. Kvinnan tillmäts fortfarande en större roll som omsorgsgivare och mannen som försörjare. Denna genusarbetsdelning, som konstituerade det borgerliga familjeidealet kom efter hand att bli ett eftersträvansvärt ideal även bland arbetare, särskilt bland dem som tillhörde en arbetararistokrati och som ville uppåt i hierarkin. Att ha en hustru som höll sig i hemmets sfär var förknippat med status varför hemmafrun kan ses som en klassmarkör som, såväl symboliskt som faktiskt, indikerade att mannen tjänade tillräckligt mycket för att hustrun skulle slippa att arbeta. Med tanke på hur svårt det måste ha varit, särskilt för arbetarkvinnor, att sköta sina barn, tungt hushållsarbete (utan avlastning med hjälp av tekniska påfund) och ett förvärvsarbete så är det inte märkligt att de också betraktade hemmafrun som ett ideal vanligen omöjligt att uppnå.

1934 nådde debatten sin kulmen i riksdagen, i båda kamrarna godkändes förslaget om att gift kvinnas yrkesrätt skulle utredas. Därmed kan man se det som att förbudsanhängarna segrade, åtminstone i denna fasen, eftersom varken företrädare för andra manlighetsstrategier eller kvinnorna i någon högre utsträckning motsatte sig en utredning. Den gifta kvinnans yrkesrätt verkade nu vara starkt ifrågasatt i riksdagen. Frangeur menar att medelvägsmanlighetens anslutning till försörjarmanligheten i riksdagen bidrog till att en hegemonisk manlighet, "som anknöt till husbondeväldets genusordning och inte längre värnade om den demokratiska emancipationen", hade utvecklats. 35] De flesta kvinnoorganisationerna kan också, menar jag, ses som ett slags medlöpare till den hegemoniska manligheten då de till slut accepterade en utredning med kravet att den blev förutsättningslös, dvs inkluderade såväl privat som offentlig arbetsmarknad samt bestod av kvinnliga sakkunniga.[36] Kvinnorna bidrog således också till att reproducera den rådande genusordningen.

\section{Männens förening förmyndarmanligheten förkroppsligad}

Även utanför riksdagen fanns en opinion för yrkesförbud för gifta kvinnor. Det fora som intog den tydligaste försörjarmanlighetsstrategin, eller för att införa ett nytt begrepp förmyndarmanlighet, i debatten var Männens förening. Denna kortlivade sammanslutning startade 1932, som en del av den maskulina tidsströmningen mot gifta kvinnors förvärvsarbete. Det är extremt tydligt hur man i denna oppositionella högerpopulistiska 
rörelse konstruerar kvinnan som "det andra" för att tala med de Beauvoir. Det är inte bara isärhållandet mellan könen som idealiseras i deras tidning; "mannen är född till arbetsledare", utan även hierarkin betonas starkt: "kvinnor behöver en fast manlig hand", dvs mannen ska vara överordnad kvinnan.[37] Kvinnan skulle hållas i hemmet på grund av sin natur vilket betydde att hon skulle avhållas från att konkurrera med mannen på arbetsmarknaden, allt för nationens och de kommande släktenas bästa.[38] Så skulle alltså både det aktuella arbetslöshets- och befolkningsproblemet bemästras. I föreningens tidning ger man uttryck för en essentilaistisk syn på könen, det är biologin som avgör hur samhället ska organiseras, varför kvinnan genom barnafödande ska vistas i hemmet. Vurmandet för nazismen blir också tydligt då man framhåller Tyskland som ett föredöme som avskedade gifta kvinnor.

Huvudfienden blev inte oväntat kvinnorörelsen då dessa högerpopulistiska strömningar kom att få betydelse inte minst genom att bidra till att kvinnorörelsen kunde "enas genom en yttre fiende".

\section{Kvinnorörelsen bjuder enat motstånd}

Det var först på 1930-talet, när diskussionen om yrkesförbud för gifta kvinnor återuppstod, som kvinnorörelsen kunde samlas kring frågan om kvinnors rätt till arbete och mer enat och kraftfullt försvara denna. Bakom denna förändring kan man skönja flera orsaker. För att tala med Foucault finns det alltid, där makten finns, en motmakt.[39] I detta fallet kan det ses som att kvinnorna utgjorde en motmakt till den hegemoniska manligheten. Men det var, menar jag, först när man kunde identifiera denna manliga makt och definiera den som en gemensam fiende som motmakten kunde samla sig och påverka strukturerna. Kvinnorna fick lättare att enas om en kollektiv identitet då de definierat en yttre fiende. Denna yttre fiende blev hotet mot demokratin, dvs högerreaktionen i Sverige mot gifta kvinnors yrkesrätt, som man menade påminde om de samtida tendenserna i Tyskland där man $\mathrm{f}$ ö lagstiftat mot denna kvinnornas rätt.[40] Hotet mot demokratin var således något som kvinnorörelsen gemensamt kunde sluta upp bakom. Även Edward Palmer Thompson menade, i sin studie över den engelska arbetarklassens uppkomst, att det är först när människor blir medvetna om att de tillhör en grupp eller klass, genom att de har gemensamma erfarenheter och intressen vilka skiljer dem från människor med andra eller motsatta intressen, som de kan handla utifrån ett klassmedvetande.[41] Detta synsätt, menar jag, kan appliceras även på kvinnorörelsen. Det var först då dessa kvinnor blev medvetna om att de som kvinnor tillhörde en grupp, genom att de delade specifika erfarenheter och intressen, som de kunde agera samfällt utifrån en feministisk medvetenhet. Precis som Thompson menar att klassen skapas i en aktiv process av mänskliga handligar och relationer kan kvinnorörelsens feministiska medvetenhet sägas ha tillkommit i en liknande process. Den, även idag aktuella, krisen i befolkningsfrågan aktualiserades också vid denna tiden och kom att genomsyra samhällsdebatten. Detta, menar Frangeur, "gav kvinnorna en viss makt i den samhälleliga diskursen".[42] Det var alltså i egenskap av mödrar och hustrur och inte primärt som samhällsmedborgare som kvinnorna kunde skaffa sig politiskt inflytande. Rädslan för att kvinnor skulle föda färre barn eller leva i synd, dvs som ogifta, om de inte fick rätt att arbeta som gifta fick en annan relevans nu än på 1920-talet eftersom befolkningsfrågan, genom makarna Myrdals försorg, definierades som en kris.

Av stor betydelse för kvinnorörelsens enande i frågan om gift kvinnas yrkesrätt var också att kvinnoidealet kunde transformeras och breddas. Istället för att som tidigare lyfta fram antingen yrkeskvinnoidealet eller husmodersidealet kunde man nu göra en lyckad kompromiss och förena dessa disparata ideal i ett och samma: den yrkesarbetande husmodern. Den tidigare dikotomin upplöstes och den nya given var, menar jag, att kvinnan skulle vara yrkeskvinna och makens tjänarinna. Trots att det handlar om idealtyper, som inte alltid motsvaras av verkligheten, blir det tydligt att genus är en föränderlig kategori och att det är människor i egenskap av historiska aktörer som genom sitt handlande, strategier och allianser bidrar till att ändra dessa. Den, med Frangeurs ord, feministiska statsstrategin blev starkare på 1930-talet och innebar att kvinnorörelsen med 
olika metoder påverkade den manliga politiska ledningen.[43] Kvinnorörelsens medlemsantal kom också att öka dramatiskt under 1930-talet och när kvinnoidealet hade ändrats talade man inte längre lika ofta om kvinnans natur och hennes kall som moder inom kvinnorörelsen. Under inflytande från nya idéer som t ex funktionalismen började istället en vision om ett nytt samhälle, om moderniteten, ta form. Traditionen med försörjarmanligheten och husmodersidealet kom således att bli utsatt för en ökad konkurrens.

\section{Resultatet av kvinnorörelsens kamp och nya yttre hot}

I riksdagen på 1930-talet var dock motståndarna till begränsningar ambivalenta och defensiva och Frangeur finner bara två företrädare för likställighetsmanligheten. Eftersom det till slut klubbades genom ett beslut om utredning kan det tolkas som att anhängarna till begränsningar av kvinnans yrkesrätt segrade, men Kvinnoarbetskommittén som tillsattes att utreda kom att få en viktig betydelse för hur frågan om gift kvinnas rätt till yrke kom att utvecklas. Istället för yrkesförbud blev kommitténs arbete snarare en manifestation för kvinnans rättigheter. Kvinnorörelsens krav på kvinnliga sakkunniga hörsammades så kommittén kom att bestå av fem kvinnor, varav de mest kända är Alva Myrdal och Kerstin Hesselgren, samt två män. Majoriteten av dessa kvinnor var dessutom kvinnosakskvinnor som hyllade yrkeskvinnan och likställigheten vilket kom att få som resultat att man lade fram ett betänkande som betonade att kvinnors arbete var viktigt. Frangeur beskriver kommitténs arbete som en "likhetsfeministisk yrkeskvinnostrategi" och exempel på "feministisk statsstrategi".[44] Hon visar hur de ledande kvinnorna i kommittén vände utredningen till en seger för gifta kvinnors rättigheter genom kunskapssamlande, opinionsbildning, kontakter med den politiska eliten och kvinnorörelsen.

När kvinnoarbetskommittén till slut lade fram sitt betänkande 1938 var det inte längre tal om att inskränka gifta kvinnors yrkesrätt. Kvinnors arbete betonades nu som något vanligt och viktigt, inte minst av ekonomiska skäl. Eftersom kvinnors arbete kunde stimulera köpkraften skulle konsumtionen öka och man skulle därigenom kunna få fart på ekonomin. Frågan handlade nu snarare om hur samhället skulle kunna främja "förvärvsarbetande kvinnors rätt till äktenskap och moderskap".[45] Det blev, trots en del turer i riksdagen 1939, ingen lagstiftning mot gifta kvinnors yrkesrätt eller begränsningar av den. Istället beslutades om en lag som förbjöd avsked av kvinnor

p g a trolovning, äktenskap, havandeskap eller barnsbörd.

Som betydelsefulla strukturella, bakomliggande faktorer till detta beslut nämner Frangeur att arbetslösheten hade sjunkit till $10 \% 1939$ och att det rådde högkonjunktur i landet. Minoritetsparlamentarismen hade ersatts av en mer stabil socialdemokratisk majoritetsregering och Sverige stod dessutom inför en annan situation 1939 med ett växande hot om att bli indraget i krig. Det fanns hos samtidens politiker en vetskap om att kvinnorna skulle behövas i produktionen, som en slags arbetskraftsreserv, då männen behövdes i försvaret. Kvinnornas arbete skulle dessutom ge ökade skatteintäkter vilka i sin tur behövdes för att finansiera de ökade försvarskostnaderna.[46] Eller med Frangeurs ord: "[...]yttre hot mot nationen istället för inre hot mot manligheten medverkade till att gifta kvinnors yrkesarbete kunde uppfattas som något positivt av en majoritet av riksdagsledamöterna".[47]

\section{Avslutande diskussion och ett försök att lyfta blicken}

Varför frågan väcktes i riksdagen om utredning av gifta kvinnors rätt till yrkesarbete står nu relativt klart. Samhället höll på att transformeras och två idealtyper av samhällen existerade parallellt sida vid sida; jordbrukssamhället och industrisamhället. Ett ben var rotat i traditionen och ett annat på väg in i moderniteten, vilket kan tydliggöras med hjälp av den medelvägsmanlighet som kom att dominera; en kluvenhet som PA Hansson kan sägas personifiera i sin inställning till gifta kvinnors yrkesrätt. Å ena sidan förespråkade 
han jämlikhet mellan könen i lagstiftningen men å andra sidan gav han uttryck för en traditionell syn på genusarbetsdelningen. Försörjarmanligheten hade tidigare varit den hegemoniska, men genom samhällstransformationen kom den att hotas, inte minst genom de landvinningar som kvinnor gjort genom myndighet och utträde på arbetsmarknaden där det dessutom rådde arbetslöshet och stor konkurrens om arbetstillfällena. Samhällets maktbaser hade förändrats, det gällde för den hegemoniska manligheten att återerövra dem genom att motsätta sig kvinnors rätt till yrkesarbete. Som vi har sett blev detta dock inte möjligt tack vare kvinnorörelsen och ett antal ledande manliga politikers handlande.

I debatten om gift kvinnas yrkesrätt blir det tydligt att det finns ett samband mellan verkligheten och det samhälleliga samtalet som förs om hur verkligheten ska uppfattas, eller m a o den samhälleliga diskursen, för att tala med Foucault. Det blir tydligt att det handlade om en kamp mellan två olika diskurser kring arbetets genus; skulle det vara manligt eller kvinnligt? Skulle en enförsörjar- eller tvåförsörjarmodell vara förhärskande? Å ena sidan finner vi de som förespråkade gifta kvinnors rätt till arbete och å andra sidan de som motsatte sig den. I denna motsättning synliggörs hur den historiskt föränderliga konstruktionen av manligt respektive kvinnligt är något som produceras i en ständig konfliktfylld process. Hur denna konstruktion av genus sker genom individers agerande och strategier som påverkar de större samhälleliga strukturerna, men också hur idéer, tankefigurer och strukturer kring manligt och kvinnligt påverkar och styr vad som är möjligt att tänka och göra. Denna tolkning av verkligheten har betydelse för hur vi väljer att agera i våra liv. När den nya diskursen konkurrerat ut den gamla och förvärvsarbetets genus blivit två kom alltfler gifta kvinnor att förvärvsarbeta. Antalet gifta kvinnor i förvärvsarbete ökade under hela 1930-, 40- och 50-talet.[48] Husmoderssidealet fick ge vika för kvinnan som yrkeskvinna och det framväxande välfärdssamhället anpassade sig efterhand genom dessa förändringar. Nya lagar och institutioner kom att införas vilka i sin tur ytterligare bidrog till att förstärka kvinnors deltagande i arbetslivet.

I Frangeurs aktörsinriktade studie ser vi hur genusordningen kan ändras genom såväl inre som yttre motsättningar; människors egna handlingar och politiska tänkande kan förändra systemet likväl som ekonomiska konjunkturer och samhälleliga omvälvningar. Att i likhet med forskare som Hirdman bortse från denna möjlighet gör kvinnor och till offer för de manliga strukturerna, vilket vi har sett att de inte alltid var; de kunde t om agera samfällt och med hjälp av statsfeministiska strategier påverka det historiska skeendet. Det går således att underminera till synes statiska strukturer underifrån och inifrån. Men som Frangeur också visar och som vi ser genom att se oss omkring idag hände inte så mycket på en metafysisk övergripande nivå i genusordningen. Där kom bilden av kvinnan som "det andra", som moder och som omsorgsgivare i hemmet att leva kvar. Normer och värderingar tar tid att förändra, men det går. Idag ses det snarare som märkligt om någon väljer att vara hemmafru framför att yrkesarbeta då det inte längre överensstämmer med den rådande samhälleliga jämställdhetsdiskursen. Verklighetens siffror avspeglar denna diskurs och låter berätta att endast tre procent av kvinnorna ägnar sig åt hushållsarbete på heltid.[49] Trots att det samtidigt som, jag redan visat, är kvinnan som är den som i störst utsträckning stannar hemma med barn och som utför obetalt

hushållsarbete. Kvinnan är fortfarande i hög utsträckning "den andra", "modern", "hemmet" och "makens tjänarinna" samtidigt som hon är yrkeskvinna. Ulla Wikander för ett intressant resonemang över sambandet mellan normer och levd verklighet: att [...]"beskriva vad kvinnlighet är, övergår lätt i att normera vad kvinnlighet bör vara. Sedan är steget kort till att den normerade kvinnligheten blir mer eller mindre förverkligad av kvinnor av kött och blod, som vill vara Sanna kvinnor".[50]

Till skillnad från andra länder, som Tyskland och USA, infördes i Sverige aldrig något yrkesförbud för gifta kvinnor under mellankrigstiden, men som Frangeur visat kunde historien blivit en annan. Det fanns en stark opinion för yrkesförbud för gifta kvinnor, men det var likställighetsfeminismen som till slut avgick med segern. Utan denna seger hade den fortsatta utvecklingen förmodligen också blivit en annan, en utveckling med mindre konkret frihet och oberoende för kvinnor. 


\section{(C) Marie Eriksson}

[1]På tal om kvinnor och män. Lathund om jämställdhet 2000, SCB, 2000, s. 52.

[2] De Beauvoir, Simone, Det andra könet, 1999, s. 404.

[3] Det bakslag för kvinnorna som Faludi talar om kom i USA på 1980-talet som en reaktion på de framsteg för kvinnor som gjorts på 1960- och 70-talet bl a inom lagstiftning och på arbetsmarknad, en reaktion som främst riktade sig mot kvinnorörelsen och feminismen, Wikander, Ulla, "Sekelskiftet 1900. Konstruktion av nygammal kvinnlighet", Det evigt kvinnliga: En historia om förändring, Manns, Ulla \& Wikander, Ulla (red), s. 8, 2001.

[4] Frangeur, Renée, Yrkeskvinna eller makens tjänarinna? Striden om yrkesrätten för gifta kvinnor i mellankrigstidens Sverige, s. 62, 1998.

[5] Edgren, Monika, Tradition och förändring. Könsrelationer, omsorgsarbete och försörjning inom Norrköpings underklass under 1800-talet, s.202, 1994.

[6] Frangeur, Renée, Yrkeskvinna eller makens tjänarinna? Striden om yrkesrätten för gifta kvinnor i mellankrigstidens Sverige, s. 62, 1998.

[7] Ibid, s. 14.

[8] Ibid, s. 96 ff.

[9] Ibid, s. 14.

[10] Ibid, s. 71.

[11] Kvinnors obetalda arbete upptar 33 timmar och 15 minuter per vecka och 20 timmar och 10 minuter för män, På tal om kvinnor och män. Lathund om jämställdhet 2000, SCB, 2000, s. 35.

[12] Frangeur, Renée, Yrkeskvinna eller makens tjänarinna? Striden om yrkesrätten för gifta kvinnor i mellankrigstidens Sverige, s. 104, 1998.

[13] Ibid, s. 85.

[14] Ibid, s. 80.

[15] Ibid, s. 86.

[16] Ibid, s. 88.

[17] Wieselgren, Greta, Den höga tröskeln. Kampen för kvinnas rätt till ämbete, 1969, s. $135 \mathrm{f}$.

[18] Frangeur, Renée, Yrkeskvinna eller makens tjänarinna? Striden om yrkesrätten för gifta kvinnor i mellankrigstidens Sverige, 1998, s.94.

[19] Järvinen, Margareta, "Makt eller vanmakt?", Kvinnovetenskaplig tidskrift 1996:1, s. 50, 1996.

[20] Connell, R.W., Maskuliniteter, s. 101, 1996.

[21] Connell, R.W., Maskuliniteter, s. 103, 1996.

[22] Frangeur, Renée, Yrkeskvinna eller makens tjänarinna? Striden om yrkesrätten för gifta kvinnor i mellankrigstidens Sverige, s. 24, 1998.

[23] Ibid, s. 104.

[24] Ibid, s. 107.

[25] Ibid, s. 348.

[26] De Beauvoir, Simone, Det andra könet, s. 15, 1999.

[27] De Beauvoir, Simone, Det andra könet, s. 17, 1999.

[28] Frangeur, Renée, Yrkeskvinna eller makens tjänarinna? Striden om yrkesrätten för gifta kvinnor i mellankrigstidens Sverige, s. 364, 1998.

[29] Ibid, s. $178 \mathrm{ff}$.

[30] Frangeur, Renée, Yrkeskvinna eller makens tjänarinna? Striden om yrkesrätten för gifta kvinnor i mellankrigstidens Sverige, s. 151, 1998.

[31] Ibid, s. 151.

[32] Ibid, s. 350.

[33] Connell, R.W., Maskuliniteter, s. 90, 1998.

[34] Siffrorna baserar sig på statistik från 1999 och totalt 36036000 ersatta dagar med föräldrapenning, den tillfälliga föräldrapenningen ej inräknad, På tal om kvinnor och män. Lathund om jämställdhet, SCB, s. 38, 2000.

[35] Frangeur, Renée, Yrkeskvinna eller makens tjänarinna? Striden om yrkesrätten för 
gifta kvinnor i mellankrigstidens Sverige, s.169, 1998.

[36] Ibid, s. 351.

[37] Ibid, s. 196.

[38] Ibid, s. 197.

[39] Järvinen, Margaretha, "Makt eller vanmakt?", Kvinnovetenskaplig tidskrift 1996:1, s. 53 - 54, 1996.

[40] Frangeur, Renée, Yrkeskvinna eller makens tjänarinna? Striden om yrkesrätten för gifta kvinnor i mellankrigstidens Sverige, s. 212, 1998.

[41] Thompson, E dward Palmer, The making of the english working class, 1980, s.8-13.

[42] Frangeur, Renée, Yrkeskvinna eller makens tjänarinna? Striden om yrkesrätten för gifta kvinnor i mellankrigstidens Sverige, s. 220, 1998.

[43] Frangeur, Renée, Yrkeskvinna eller makens tjänarinna? Striden om yrkesrätten för gifta kvinnor i mellankrigstidens Sverige, s. 226, 1998.

[44] Ibid, s. $268 \mathrm{f}$.

[45] Frangeur, Renée, Yrkeskvinna eller makens tjänarinna? Striden om yrkesrätten för gifta kvinnor i mellankrigstidens Sverige, s. 267, 1998.

[46] Ibid, s. 343.

[47] Ibid, s. 357.

[48] Ibid, s. 366.

[49] Siffrorna baserar sig på en undersökning från 1996 som avser åldersgruppen 25-54 år, SOU 1997:137, "Yrkessegregeringen mellan kvinnor och män", Christina Jonung, s. 65, 1997.

[50] Wikander, Ulla, "Sekelskiftet 1900 - Konstruktion av nygammal kvinnlighet", Det evigt kvinnliga. En historia om förändring, Manns, Ulla \& Wikander, Ulla (red), s. 7, 2001. 